\title{
Commentary: The need to RIOT (return to intended oncologic treatment) after lung cancer surgery
}

\author{
Jessica S. Donington, MD, MSCR, ${ }^{\mathrm{a}}$ and Linda W. Martin, MD, MPH
}

\footnotetext{
From the a Department of Surgery, University of Chicago Medicine and Biologic Sciences, Chicago, Ill; and ${ }^{\mathrm{b}} \mathrm{Di}-$ vision of Cardiac and Thoracic Surgery, Department of Surgery, University of Virginia, Charlottesville, Va. Disclosures: J.S.D.: Honorarium, travel, and advisory board reimbursements from AstraZeneca. L.W.M. has nothing to disclose with regard to commercial support.

Received for publication March 15, 2019; accepted for publication March 18, 2019.

Address for reprints: Jessica S. Donington, MD, MSCR, Department of Surgery, University of Chicago Medicine and Biologic Sciences, 5841 South Maryland Ave, Suite E500, MC 5040, Chicago, IL 60637 (E-mail: jdonington@uchicago.edu).

J Thorac Cardiovasc Surg 2019;158:287-8

$0022-5223 / \$ 36.00$

Copyright (c) 2019 by The American Association for Thoracic Surgery

https://doi.org/10.1016/j.jtcvs.2019.03.105
}

Novel protocols aimed to increase the efficacy and tolerability of non-small cell lung cancer (NSCLC) resections now expand well beyond minimally invasive incisions and extend throughout the perioperative period. Enhanced recovery protocols (ERPs) are revolutionizing surgical care. The European Society of Thoracic Surgeons and Enhanced Recovery After Surgery Society recently published Enhanced Recovery After Surgery recommendations ${ }^{1}$ that include evidence-based care recommendations throughout the perioperative experience, emphasizing smoking cessation, minimally invasive surgery, decreased fasting, opioid-sparing analgesia, early mobilization, and increased patient education. The MD Anderson thoracic surgeons are leaders in ERP use in the United States and reported decreased length of stay and cardiopulmonary complications with implementation of their ERP for patients undergoing thoracic surgery. ${ }^{2}$

There is also evidence suggesting that the value of ERP in patients with cancer goes beyond the perioperative period. Surgical complications and postoperative debility can hinder the ability of patients to undergo subsequent oncologic therapies and negate the value of surgical intervention. Return to intended oncologic treatment (RIOT) is a novel quality indicator in surgical oncology.

Initially evaluated in hepatic resections for cancer, the inability to RIOT after surgery correlated with shorter disease-free and overall survival. ${ }^{3}$ Innovative work from Nelson and colleagues ${ }^{4}$ outlines how the initiation of ERP for patients with early-stage NSCLC at MD Anderson resulted in increased rates of adjuvant chemotherapy use in eligible patients. They demonstrated that ERP helped patients with early-stage NSCLC to RIOT. Similar findings regarding ERP and RIOT are reported in breast and pancreatic surgery. ${ }^{5}$

An additional long-term oncologic benefit of ERP is reduced perioperative opioid consumption. NSCLC cells have mu-opioid receptors, and stimulation results in cell

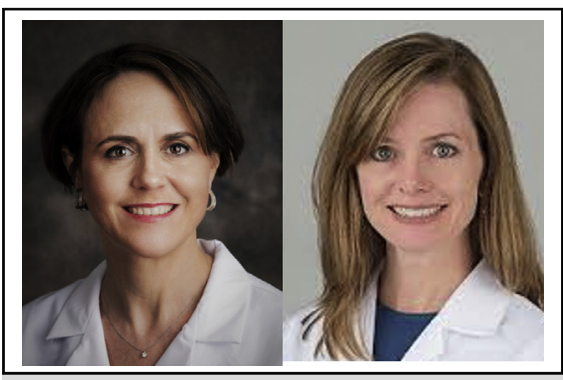

Jessica S. Donington, MD, MSCR, and Linda W. Martin, MD, MPH

Central Message

Enhanced recovery programs can improve long-term cancer outcome by facilitating return to indicated oncologic treatments and decreasing mitogenic stimulation of muopioid receptors on cancer cells.

See Article page 279.

proliferation, growth, and metastasis. ${ }^{6,7}$ Increased postoperative opioid consumption correlates with increased recurrence rates after resection in early-stage NSCLC. ${ }^{8} \mathrm{Re}$ ductions as much as $74 \%$ in morphine equivalents are achievable with initiation of ERP in patients with NSCLC. ${ }^{9}$ In this way, ERP may improve cancer outcomes by reducing exposure to the potentially mitogenic effect of opioids.

Lung cancer care is increasingly multimodal. Thoracic surgeons need to think beyond the immediate perioperative outcomes and consider the impact of our interventions in a broader treatment paradigm. This requires implementation of processes that lessen the negative physiologic impact of resections, speed recovery, and facilitate additional oncologic therapies.

\section{References}

1. Batchelor TJP, Rasburn NJ, Abdelnour-Berchtold E, Brunelli A, Cerfolio RJ Gonzalez M, et al. Guidelines for enhanced recovery after lung surgery: recommendations of the Enhanced Recovery After Surgery (ERAS(R)) Society and the European Society of Thoracic Surgeons (ESTS). Eur J Cardiothorac Surg. 2019;55:91-115.

2. Van Haren RM, Mehran RJ, Mena GE, Correa AM, Antonoff MB, Baker CM, et al. Enhanced recovery decreases pulmonary and cardiac complications after thoracotomy for lung cancer. Ann Thorac Surg. 2018;106:272-9.

3. Aloia TA, Zimmitti G, Conrad C, Gottumukalla V, Kopetz S, Vauthey JN. Return to intended oncologic treatment (RIOT): a novel metric for evaluating the quality of oncosurgical therapy for malignancy. J Surg Oncol. 2014;110:107-14.

4. Nelson D, Mehran RJ, Mitchell K, Correa AM, Sepesi B, Antonoff MB, et al. Enhanced recovery after thoracic surgery is associated with improved adjuvant 
chemotherapy for non-small cell lung cancer. J Thorac Cardiovasc Surg. 2019; 158:279-86.e1.

5. Kim BJ, Caudle AS, Gottumukkala V, Aloia TA. The impact of postoperative complications on a timely return to intended oncologic therapy (RIOT): the role of enhanced recovery in the cancer journey. Int Anesthesiol Clin. 2016;54:e33-46.

6. Mathew B, Lennon FE, Siegler J, Mirzapoiazova T, Mambetsariev N, Sammani S, et al. The novel role of the mu opioid receptor in lung cancer progression: a laboratory investigation. Anesth Analg. 2011;112:558-67.

7. Lennon FE, Mirzapoiazova T, Mambetsariev B, Poroyko VA, Salgia R, Moss J, et al. The Mu opioid receptor promotes opioid and growth factor-induced prolif- eration, migration and epithelial mesenchymal transition (EMT) in human lung cancer. PLoS One. 2014;9:e91577.

8. Maher DP, Wong W, White PF, McKenna R Jr, Rosner H, Shamloo B, et al. Association of increased postoperative opioid administration with non-small-cell lung cancer recurrence: a retrospective analysis. Br J Anaesth. 2014;113(Suppl 1): i88-94.

9. Martin LW, Sarosiek BM, Harrison MA, Hedrick T, Isbell JM, Krupnick AS, et al. Implementing a thoracic enhanced recovery program: lessons learned in the first year. Ann Thorac Surg. 2018;105: 1597-604. 